The

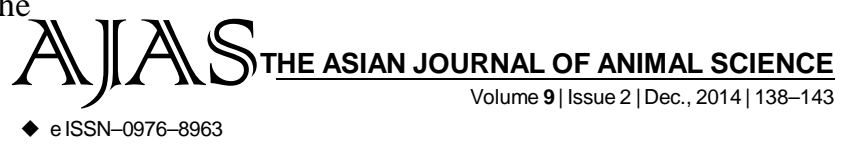

DOI : 10.15740/HAS/TAJAS/9.2/138-143

Visit us | www.researchjournal.co.in

RESEARCH ARTICLE.........

\title{
A study on the quality changes during baking of Indian mackerel, Rastrelliger kanagurta
}

\section{S.R. SENAPATI, R. MISHRA AND H.S. SWAIN}

Author for Corresponding -

\section{R. MISHRA}

College of Fisheries (O.U.A.T.),

Rangailunda, BERHAMPUR

(ODISHA) INDIA

Email: rmishrafishcol@yahoo.com

See end of the article for

Coopted authors'

\begin{abstract}
Indian mackerel, Rastrelliger kanagurta, available along Odisha coast in abundance was considered for baking and effect of baking on quality changes has been studied in the present paper. The dressed fish pieces of 50 to $60 \mathrm{~g}$ each were marinaded with spice mixture at room temperature for $1 \mathrm{hr}$ for spices to penetrate into the fish muscle. The heat processing time of fish pieces were standardised for $75 \mathrm{~min}$ at $15 \mathrm{psi}\left(121.2^{\circ} \mathrm{C}\right)$ so as to make the fish bones soft and palatable. Baking time was standardised at $160^{\circ} \mathrm{C}$ for a period of $60 \mathrm{~min}$. The proximate composition of fish and baked fish revealed that moisture content decreased by 20.65 per cent whereas crude protein and lipid content increased significantly by 59.28 per cent and 19.56 per cent, respectively $(\mathrm{p}<0.05)$. The chemical and microbiological changes due to baking the fish were also analysed and discussed. The organoleptic evaluation of baked mackerel fish samples was conducted in a 5-point hedonic scale. Besides, the softness of the bones its palatability improved the overall acceptability of baked product to a higher degree.
\end{abstract}

KEY WORDS...... Baking, Mackerel, Quality changes

HOW TO CITE THIS ARTICLE - Senapati, S.R., Mishra, R. and Swain, H.S. (2014). A study on the quality changes during baking of Indian mackerel, Rastrelliger kanagurta. Asian J. Animal Sci., 9(2) : 138-143.

ARTICLE CHRONICLE - Received : 13.06.2014; Revised : 28.10.2014; Accepted : 14.11.2014 